\title{
Cytotoxic and novel skeleton compounds from the heartwood of Chamaecyparis obtusa var. formosana
}

\author{
Shih-Chang Chien, ${ }^{\mathrm{a}}$ Jang-Yang Chang, ${ }^{\mathrm{b}, \mathrm{c}}$ Ching-Chuan Kuo, ${ }^{\mathrm{b}}$ Cheng-Chih Hsieh, ${ }^{\mathrm{d}}$ \\ Ning-Sun Yang ${ }^{\mathrm{e}}$ and Yueh-Hsiung Kuo ${ }^{\mathrm{a}, \mathrm{e}, \mathrm{f}, \mathrm{g}, *}$ \\ ${ }^{a}$ Department of Chemistry, National Taiwan University, Taipei 106, Taiwan \\ ${ }^{\mathrm{b}}$ Division of Cancer Research, National Health Research Institutes, Taipei 114, Taiwan \\ ${ }^{\mathrm{c}}$ Division of Hematology/Oncology, Tri-Service General Hospital, National Defense Medical Center, Taipei 114, Taiwan \\ ${ }^{\mathrm{d}}$ Graduate Institute of Medical Sciences, National Defense Medical Center, Taipei 114, Taiwan \\ ${ }^{\mathrm{e}}$ Agricultural Biotechnology Research Center, Academia Sinica, Taipei 115, Taiwan \\ ${ }^{\mathrm{f}}$ College of Pharmacy, China Medical University, Taichung 404, Taiwan \\ ${ }^{\mathrm{g}}$ Research Center of Food and Biomolecules, College of Bioresources and Agriculture, National Taiwan University, Taipei 106, Taiwan
}

Received 25 September 2006; revised 28 December 2006; accepted 4 January 2007

Available online 7 January 2007

\begin{abstract}
The novel skeleton compounds, chamaecypanone C (3) and obtunorlignan A (4) were isolated from the heartwood of Chamaecyparis obtusa var. formosana. The structure of $\mathbf{3}$ was elucidated as a dimeric of monoterpene and norlignan with tricyclo$\left[5.2 .2 .0^{2.6}\right]$ undecane and the structure of $\mathbf{4}$ was elucidated as a norlignan skeleton by spectroscopic methods. Compound $\mathbf{3}$ exhibits potent cytotoxic activity against several human cancer cells with $\mathrm{IC}_{50}$ values ranging from 0.19 to $0.52 \mu \mathrm{M}$, whereas 4 has no activity.

(C) 2007 Published by Elsevier Ltd.
\end{abstract}

The trunk of Chamaecyparis obtusa var. formosana Rehd. (Taiwan hinoki; Cupressaceae) is an important building material in Taiwan due to its decay-resistant characteristics. We have previously investigated the chemical components of the heartwood of this plant, and found various monoterpenes, sesquiterpenes, diterpenes and lignans. ${ }^{1-8}$ Two interesting compounds, bicyclo[2.2.2] octane skeleton diterpenes, obtunone $(\mathbf{1})^{1}$ and 8,12-dihydroxydielmentha-5,9-diene-7,11-dione $(2)^{1}$ were observed. The biosyntheses of $\mathbf{1}$ and $\mathbf{2}$ were proposed as the adducts from 1-hydroxymetha-3,5dien-2-one with myrcene and itself, respectively, via bio-Diels-Alder reaction. Further detailed investigation of the same extraction from the heartwood has furnished two novel skeleton compounds, chamaecypanone C (3) and obtunorlignan A (4). The structural elucidation of these compounds are reported here.

The air-dried slices of heartwood of C. obtusa var. formosana were extracted with $\mathrm{Me}_{2} \mathrm{CO}$ at room tempera-

Keywords: Chamaecyparis obtusa var. formosana; Dimer of monoterpene and norlignan; Norlignan.

* Corresponding author. Tel.: +886 2 33661671; fax: +886 2 23636359; e-mail: yhkuo@ntu.edu.tw

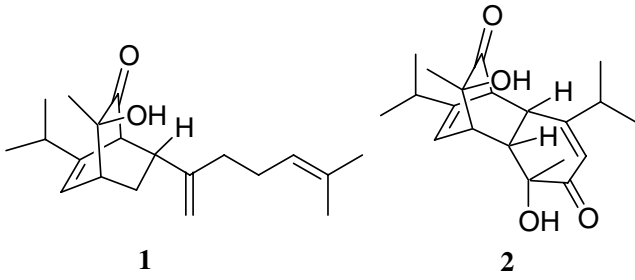

ture. After evaporation of $\mathrm{Me}_{2} \mathrm{CO}$, the extract was partitioned with an EtOAc-water mixture to give an EtOAc-soluble fraction and an aqueous phase. The EtOAc-soluble fraction $(680 \mathrm{~g})$ was repeatedly chromatographed on $\mathrm{SiO}_{2}$ column and HPLC [Merck Lichrosorb Si $60,250 \times 10 \mathrm{~mm}$ i.d., EtOAc- $\mathrm{CH}_{2} \mathrm{Cl}_{2}$ (3:2)] to give chamaecypanone $\mathrm{C} \mathrm{(3)}$ and obtunorlignan A (4).

Chamaecypanone C (3) was isolated as an amorphous solid with a positive optical rotation $\left[[\alpha]_{\mathrm{D}}^{23}+175.7(c\right.$ $0.85, \mathrm{MeOH})]$ and $\mathrm{UV} \lambda_{\max }$ at 227,282 and $302 \mathrm{~nm}$. The positive-ion fast atom bombardment (FAB-MS) of 3 showed a quasi-molecular ion peak at $\mathrm{m} / z 431$ $(\mathrm{M}+\mathrm{H})^{+}$, and the molecular formula $\mathrm{C}_{27} \mathrm{H}_{26} \mathrm{O}_{5}$ of 3 was resolved using high-resolution MS measurement. ${ }^{9}$ 
The IR ( $\mathrm{KBr}$ ) spectrum of $\mathbf{3}$ showed absorption bands at $3379,1740,1701,1616$ and $1517 \mathrm{~cm}^{-1}$ ascribable to hydroxyl, carbonyl and aromatic groups. In the UV spectrum of 3, absorption maxima were observed at 227, 282 and $302 \mathrm{~nm}$ revealing the presence of the conjugated system. The ${ }^{1} \mathrm{H}$ NMR (acetone- $d_{6}$ ) spectrum ${ }^{9,10}$ of $\mathbf{3}$ showed an isopropyl group attached to a double bond [1380 and $1368 \mathrm{~cm}^{-1}, \delta 0.91$ and 0.94 (3H each, d, $J=6.8 \mathrm{~Hz}), 2.29(1 \mathrm{H}$, sep, $J=6.8 \mathrm{~Hz})]$, one trisubstituted double bond $[\delta 5.83(1 \mathrm{H}, \mathrm{dd}, J=6.5,1.2 \mathrm{~Hz}, \mathrm{H}-$ 5)], a methyl group attached to a quaternary carbon bearing a hydroxyl group $[\delta 1.26(3 \mathrm{H}, \mathrm{s}, \mathrm{H}-15)]$, a methine proton located between the carbonyl and olefinic groups $(\delta 3.71, \mathrm{~d}, J=1.2 \mathrm{~Hz}, \mathrm{H}-1)$ and a methine proton considered to be linked between an olefinic and methine group $(\delta 3.18,1 \mathrm{H}, \mathrm{dd}, J=6.5,3.5 \mathrm{~Hz}, \mathrm{H}-4)$. These data together with ${ }^{13} \mathrm{C}$ NMR data $\left[\delta_{\mathrm{C}} 59.8(\mathrm{CH}\right.$, C-1), 47.8 (CH, C-4), 124.5 (CH, C-5), 147.9 (C, C-6), 209.8 (C, C-7), 71.0 (C, C-8), 33.9 (CH, C-12), 20.7 $\left(\mathrm{CH}_{3}, \mathrm{C}-13\right), 21.2\left(\mathrm{CH}_{3}, \mathrm{C}-14\right)$ and $\left.26.7\left(\mathrm{CH}_{3}, \mathrm{C}-15\right)\right]$ are also similar to $p$-methenone moiety in compounds 1 and 2. The partial structure was further proved by ${ }^{1} \mathrm{H}-{ }^{1} \mathrm{H}$ COSY, HMBC (see Fig. 1) and NOESY spectra (see Fig. 2). The ${ }^{1} \mathrm{H}-{ }^{1} \mathrm{H}$ COSY experiment on 3 indicated the presence of partial structure in bold lines as in Figure 1. The pronounced NOESY correlation between $\mathrm{H}-5$ and $\mathrm{H}_{3}-15$ established two protons are in syn face. The differences between $\mathbf{3}$ and $\mathbf{2}$ are that $\mathrm{H}-2$ is not observed, and $\mathrm{H}-1$ only couples with $\mathrm{H}-5$ via allylic coupling. Two $p$-hydroxyphenyl groups were obviously revealed from the ${ }^{1} \mathrm{H}$ NMR data $[\delta 6.73$ and 7.35 (2H each, d, $J=8.7 \mathrm{~Hz}, \mathrm{H}_{2}-3^{\prime}, 5^{\prime}$ and $\mathrm{H}_{2}-2^{\prime}, 6^{\prime}$, respectively), 6.80 and $7.65(2 \mathrm{H}$ each, $\mathrm{d}, J=8.7 \mathrm{~Hz}$, $\mathrm{H}_{2}-3^{\prime \prime}, 5^{\prime \prime}$ and $\mathrm{H}_{2}-2^{\prime \prime}, 6^{\prime \prime}$, respectively) and 8.23, 8.50 (1H each, exchangeable)]. H-1 exhibited NOESY correlations with $\mathrm{H}-12,13,14$, and $\mathrm{H}-2^{\prime}, 6^{\prime}$, as well as HMBC correlation with $\mathrm{C}-1^{\prime}$. This evidence suggests that the $p$ -

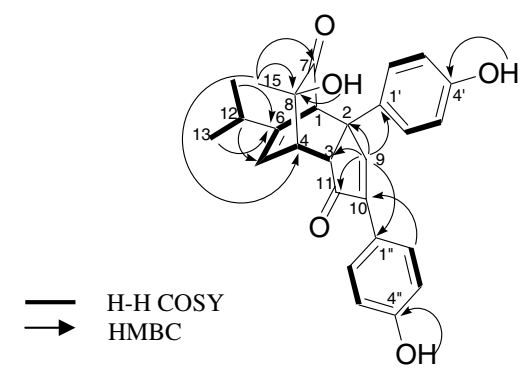

Figure 1. ${ }^{1} \mathrm{H}-{ }^{1} \mathrm{H}$ COSY and key HMBC correlations of 3.

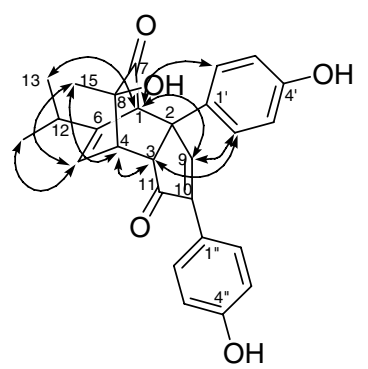

Figure 2. Key NOESY correlations of 3. hydroxyphenyl group linked at $\mathrm{C}-2$ with $\beta$-orientation. The remaining $\mathrm{sp}^{3}$ methine proton at $\delta 3.58(\mathrm{~d}$, $J=3.5 \mathrm{~Hz})$ was assigned as $\mathrm{H}-3$ due to coupling with $\mathrm{H}-4(\delta 3.18, \mathrm{dd}, J=6.5,3.5 \mathrm{~Hz})$ and $\mathrm{HMBC}$ correlation with C-8, C-9 $\left(\delta_{\mathrm{C}} 71.0,160.1\right)$ and $\mathrm{C}-1^{\prime}\left(\delta_{\mathrm{C}} 133.1\right)$. The pronounced NOESY correlation between $\mathrm{H}-3$ and $\mathrm{H}-$ $2^{\prime}, 6^{\prime}$ confirmed the H-3 and one of $p$-hydroxyphenyl group are in syn face. The UV, IR $\left(1740 \mathrm{~cm}^{-1}\right)$ and ${ }^{1} \mathrm{H}$ and ${ }^{13} \mathrm{C}$ NMR $\left[\delta_{\mathrm{C}} 209.0(\mathrm{C}-11), \delta_{\mathrm{H}} 7.58\left(\mathrm{H}-9, \delta_{\mathrm{C}}\right.\right.$ $160.1), \delta_{\mathrm{C}} 142.8$ (C-10)] signals indicated the presence of cyclopentenone with a $p$-hydroxyphenyl substituent at the $\alpha$-position. Fifteen indices of hydrogen deficiency (IHD) were determined from the ${ }^{13} \mathrm{C}$ NMR, DEPT and HR-FAB-MS experiments. On the basis of the above evidence, the structure of $\mathbf{3}$ was elucidated as shown in the formula, a dimeric of monoterpene and norlignan with tricyclo[5.2.2.0 $\left.0^{2.6}\right]$ undecane skeleton.

The absolute configuration of $\mathbf{2}$ was obtained from CD measurements and determined to be $8 R$. Compound $\mathbf{2}$, isolated from this plant, expressed the same specific rotation value as isolated from Callitric macleayana. ${ }^{11,12}$ Based on the same biological pathway, C-8 in chamaecypanone $\mathrm{C}$ was assigned as $R$-configuration. The biosynthesis of this novel skeleton may occur from 1-hydroxymentha-3,5-dien-2-one (5) and 1,3-bis(4-hydroxyphenyl)cyclopenta-1,3-diene (6, a norlignan) via endo addition of bio-Diels-Alder reaction, and then was oxidized to produce compound $\mathbf{3}$.
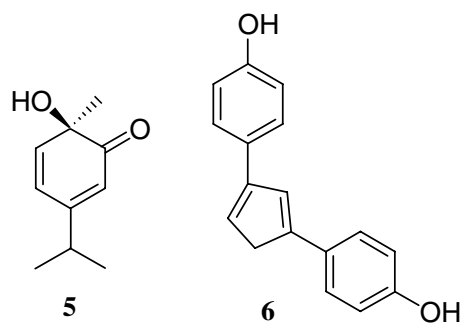

Obtunorlignan A (4) was isolated as an amorphous solid with negative optical rotation $\left[[\alpha]_{\mathrm{D}}^{20}-10.3\right.$ (c 0.35 , $\mathrm{MeOH})]$ and $\mathrm{UV}_{\max }$ at 225 and $255 \mathrm{~nm}$. The IR spectrum showed aromatic $\left(1616\right.$ and $\left.1516 \mathrm{~cm}^{-1}\right)$ and hydroxy $\left(3387 \mathrm{~cm}^{-1}\right)$ groups. The ${ }^{1} \mathrm{H}$ NMR spectrum ${ }^{13,14}$ revealed two $p$-hydroxyphenyls $[\delta 6.75,7.30(2 \mathrm{H}$ each, $\mathrm{d}, J=8.8 \mathrm{~Hz})$ and $6.77,7.26(2 \mathrm{H} \mathrm{each}, \mathrm{d}, J=8.8 \mathrm{~Hz})]$. Three lower shift oxygenated $\mathrm{sp}^{3}$ carbons at $\delta_{\mathrm{C}} 66.2$ $\left(\mathrm{CH}_{2}, \mathrm{C}-9\right), 69.0\left(\mathrm{CH}, \mathrm{C}-8^{\prime}\right)$ and $82.6\left(\mathrm{CH}, \mathrm{C}-7^{\prime}\right)$ indicated the remaining 2O-atoms which existed as one ether and one alcohol group. One trisubstitutes olefinic proton at the lower field $\delta_{\mathrm{H}} 6.04(\mathrm{H}-8$, resonanted at $\delta_{\mathrm{C}}$ 124.5) exhibited coupling with $\mathrm{H}_{2}-9$ with $\mathrm{dd}$, $J=2.4,2.0 \mathrm{~Hz}$ and conjugating with $p$-hydroxyphenyl $\left(\mathrm{UV}_{\max } 255 \mathrm{~nm}\right) . \mathrm{H}-8^{\prime}$ expressed signal at $\delta_{\mathrm{H}} 4.64$ with diaxial coupling to $\mathrm{H}^{\prime} 7^{\prime}\left(\delta_{\mathrm{H}} 4.41, J=6.8 \mathrm{~Hz}\right)$ and homoallylic compiling to $\mathrm{H}-9 \beta\left(\delta_{\mathrm{H}} 4.22, J=3.6 \mathrm{~Hz}\right)$ and to $\mathrm{H}-9 \alpha\left(\delta_{\mathrm{H}} 4.36, J=2.4 \mathrm{~Hz}\right)$. Except with geminal coupling $(J=16.8 \mathrm{~Hz}), \mathrm{H}-9 \beta$ and $\mathrm{H}-9 \alpha$ exhibited vicinal coupling with $\mathrm{H}-8$ with $J=2.0$ and $2.4 \mathrm{~Hz}$, respectively. From the above evidence, the gross structure of $\mathbf{4}$ can be elucidated as 2,4-bis-(4-hydroxyphenyl)-3-hydroxy-4,5dehydrotetrahydropyranane. The further proof was confirmed from its HMBC correlation. The HMBC 


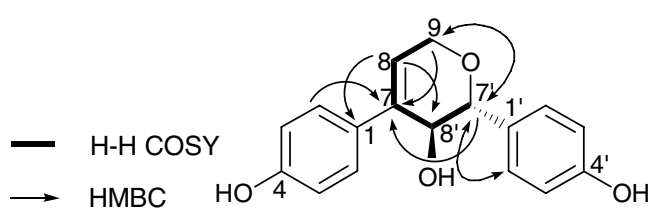

Figure 3. ${ }^{1} \mathrm{H}-{ }^{1} \mathrm{H}$ COSY and key HMBC correlations of 4

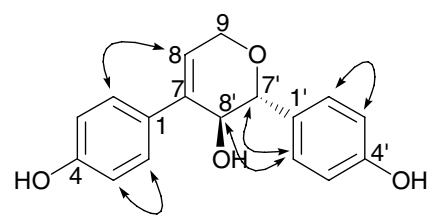

Figure 4. Key NOESY correlations of 4.

Table 1. Cytotoxicity of 3 and 4

\begin{tabular}{llcl}
\hline Cell line & \multicolumn{3}{c}{ IC50 $(\mu \mathrm{M})$} \\
\cline { 2 - 4 } & $\mathbf{3}$ & $\mathbf{4}$ & $\mathrm{VP}^{-16^{\mathrm{a}}}$ \\
\hline KB & $0.19 \pm 0.08$ & $>50$ & $1.10 \pm 0.12$ \\
HONE-1 & $0.24 \pm 0.09$ & $>50$ & $0.51 \pm 0.35$ \\
TSGH & $0.52 \pm 0.11$ & $>50$ & $2.74 \pm 0.94$ \\
\hline
\end{tabular}

${ }^{\mathrm{a}}$ Positive control substance.

spectrum (Fig. 3) indicated that the two p-hydroxyphenyl groups were located at $\mathrm{C}-7$ and $\mathrm{C}-7^{\prime}$. The ${ }^{1} \mathrm{H}-{ }^{1} \mathrm{H}$ COSY experiment on 4 indicated the presence of partial structure in bold lines as in Figure 3. H-8' and H-2 ${ }^{\prime}, \mathrm{H}-$ $6^{\prime}$ have NOESY (Fig. 4) correlation to give the same side evidence. The coupling constant $(J=6.8 \mathrm{~Hz})$ between $\mathrm{H}-7^{\prime}$ and $\mathrm{H}-8^{\prime}$ determined the quasi-diaxial correlation. On the basis of the above evidence, the structure of (4) was elucidated.

Chamaecypanone C (3) and obtunorlignan A (4) were evaluated for their cytotoxicity against KB (human oral epidermoid carcinoma), HONE-1 (human nasopharyngeal carcinoma) and TSGH (human gastric carcinoma) cells. The cell viability were assessed through a methylene blue dye assay, ${ }^{15}$ and the results are shown in Table 1.

Compound 3 exhibited the higher susceptibility with $\mathrm{IC}_{50}$ ranges from 0.19 to $0.52 \mu \mathrm{M}$ than that of the clinically used anticancer drug etoposide (VP-16). However, 4 displayed no cytotoxic activity. Further studies, aiming to investigate a possible mechanism responsible for 3-mediated cytotoxic effect among human cancer cells, are actually in progress.

\section{Acknowledgments}

The authors thank the National Science Council of the Republic of China, for financial support.

\section{References and notes}

1. Kuo, Y. H.; Chen, C. H.; Huang, S. L. Chem. Pharm. Bull. 1998, 46, 181-183.

2. Kuo, Y. H.; Chen, C. H.; Huang, S. L. J. Nat. Prod. 1998, $61,829-831$.

3. Kuo, Y. H.; Chen, C. H. Tetrahedron Lett. 2001, 42, 29852986.

4. Kuo, Y. H.; Chen, C. H.; Chiang, Y. M. Tetrahedron Lett. 2001, 42, 6731-6735.

5. Kuo, Y. H.; Chen, C. H.; Chien, S. C.; Lin, Y. L. J. Nat. Prod. 2002, 65, 25-28.

6. Kuo, Y. H.; Chen, C. H.; Lin, Y. L. Chem. Pharm. Bull. 2002, 50, 978-980.

7. Kuo, Y. H.; Chen, C. H.; Wein, Y. S. Helv. Chem. Acta 2002, 85, 2657-2663.

8. Kuo, Y. H.; Chen, C. H.; Chien, S. C.; Lin, H. C. Chem. Pharm. Bull. 2004, 52, 764-766.

9. Compound 3: amorphous solid; $[\alpha]_{\mathrm{D}}^{23}+175.7$ (c 0.85 , $\mathrm{MeOH}$ ); high-resolution positive-ion FAB-MS calcd for $\mathrm{C}_{27} \mathrm{H}_{27} \mathrm{O}_{5} \quad(\mathrm{M}+\mathrm{H})^{+}$431.1935, found 431.1930; UV $(\mathrm{MeOH}, \log \varepsilon) 227$ (4.32), 282 (3.93), 302 (3.86, sh) nm; IR (KBr) 3379, 1740, 1701, 1616, 1517, 1474, 1380, 1368, $1271,1225,1174,837,757 \mathrm{~cm}^{-1}$; positive-ion FAB-MS $m / z 431(\mathrm{M}+\mathrm{H})^{+} ;{ }^{1} \mathrm{H}$ NMR (acetone- $\left.d_{6}\right) \delta 0.91,0.94(3 \mathrm{H}$ each, d, $\left.J=6.8 \mathrm{~Hz}, \mathrm{H}_{3}-13,14\right), 1.26\left(3 \mathrm{H}, \mathrm{s}, \mathrm{H}_{3}-15\right), 2.29$ $(1 \mathrm{H}$, sep, $J=6.8 \mathrm{~Hz}, \mathrm{H}-12), 3.18(1 \mathrm{H}, \mathrm{dd}, J=6.5,3.5 \mathrm{~Hz}$, $\mathrm{H}-4), 3.58(1 \mathrm{H}, \mathrm{d}, J=3.5 \mathrm{~Hz}, \mathrm{H}-3), 3.71(1 \mathrm{H}, \mathrm{d}$, $J=1.2 \mathrm{~Hz}, \mathrm{H}-1$ ), 4.41, 8.23, 8.50 (1H each, br s, OH-8, $\left.4^{\prime}, 4^{\prime \prime}\right), 5.83(1 \mathrm{H}, \mathrm{dd}, J=6.5,1.2 \mathrm{~Hz}, \mathrm{H}-5), 6.73(2 \mathrm{H}, \mathrm{d}$, $\left.J=8.7 \mathrm{~Hz}, \mathrm{H}-3^{\prime}, 5^{\prime}\right), 6.80\left(2 \mathrm{H}, \mathrm{d}, J=8.7 \mathrm{~Hz}, \mathrm{H}-3^{\prime \prime}, 5^{\prime \prime}\right)$, $7.35\left(2 \mathrm{H}, \mathrm{d}, J=8.7 \mathrm{~Hz}, \mathrm{H}-2^{\prime}, 6^{\prime}\right), 7.58(1 \mathrm{H}, \mathrm{s}, \mathrm{H}-9), 7.65$ $\left(2 \mathrm{H}, \mathrm{d}, J=8.7 \mathrm{~Hz}, \mathrm{H}-2^{\prime \prime}, 6^{\prime \prime}\right) ;{ }^{13} \mathrm{C}$ NMR (acetone- $\left.d_{6}\right) \delta_{\mathrm{C}}$ 20.7 (C-13), 21.2 (C-14), 26.7 (C-15), 33.9 (C-12), 47.8 (C4), 53.5 (C-2), 53.6 (C-3), 59.8 (C-1), 71.0 (C-8), 116.1 (C$\left.3^{\prime}, 5^{\prime}, 3^{\prime \prime}, 5^{\prime \prime}\right), 123.7\left(\mathrm{C}-1^{\prime \prime}\right), 124.5(\mathrm{C}-5), 129.4\left(\mathrm{C}-2^{\prime \prime}, 6^{\prime \prime}\right)$, $129.5\left(\mathrm{C}-2^{\prime}, 6^{\prime}\right), 133.1\left(\mathrm{C}-1^{\prime}\right), 142.8$ (C-10), 147.9 (C-6), $157.0\left({\mathrm{C}-4^{\prime}}^{\prime}\right), 158.8\left(\mathrm{C}-4^{\prime \prime}\right), 160.1$ (C-9), 209.0 (C-11), 209.8 (C-7).

10. The ${ }^{1} \mathrm{H}$ and ${ }^{13} \mathrm{C}$ NMR spectra of 3 were assigned with the aid of NOESY, ${ }^{1} \mathrm{H}-{ }^{1} \mathrm{H}$ COSY, DEPT, HSQC and HMBC experiments.

11. Carmam, R. M.; Lambert, L. K.; Robinson, W. T.; Van Dongen, J. M. A. Aust. J. Chem. 1986, 39, 1843-1850.

12. Carmam, R. M.; Owsia, S.; Van Dongen, J. M. A. Aust. J. Chem. 1987, 40, 333-340.

13. Compound 4: amorphous solid; $[\alpha]_{\mathrm{D}}^{20}-10.3 \quad(c) 0.35$, $\mathrm{MeOH}$ ); high-resolution EI-MS calcd for $\mathrm{C}_{17} \mathrm{H}_{16} \mathrm{O}_{4-}$ $\mathrm{H}_{2} \mathrm{O}\left(\mathrm{M}-\mathrm{H}_{2} \mathrm{O}\right)^{+}$266.0939, found 266.0941; UV $(\mathrm{MeOH}$, $\log \varepsilon) 225$ (4.02, sh), 255 (4.01) nm; IR (KBr) 3387, 1616, 1516, 1233, $833 \mathrm{~cm}^{-1}$; EI-MS (rel. int. \%) $\mathrm{m} / \mathrm{z} 266$ $\left(\mathrm{M}-\mathrm{H}_{2} \mathrm{O}\right)^{+}(3), 250$ (4), 163 (17), 162 (100), 133 (68), 121 (17); ${ }^{1} \mathrm{H}$ NMR (methanol- $\left.d_{4}\right) \quad \delta \quad 4.22$ (1H, ddd, $J=16.8, \quad 3.6,2.0 \mathrm{~Hz}, \mathrm{H}-9), 4.36(1 \mathrm{H}, \mathrm{dt}, J=16.8$, $2.4 \mathrm{~Hz}, \mathrm{H}-9), 4.41\left(1 \mathrm{H}, \mathrm{d}, J=6.8 \mathrm{~Hz}, \mathrm{H}-7^{\prime}\right), 4.64(1 \mathrm{H}$, $\left.\mathrm{ddd}, J=6.8,3.6,2.4 \mathrm{~Hz}, \mathrm{H}-8^{\prime}\right), 6.04(1 \mathrm{H}, \mathrm{dd}, J=2.4$, $2.0 \mathrm{~Hz}, \mathrm{H}-8), 6.75(2 \mathrm{H}, \mathrm{d}, J=8.8 \mathrm{~Hz}, \mathrm{H}-3,5), 6.77(2 \mathrm{H}, \mathrm{d}$, $\left.J=8.8 \mathrm{~Hz}, \mathrm{H}-3^{\prime}, 5^{\prime}\right), 7.26\left(2 \mathrm{H}, \mathrm{d}, J=8.8 \mathrm{~Hz}, \mathrm{H}-2^{\prime}, 6^{\prime}\right)$, $7.30(2 \mathrm{H}, \mathrm{d}, J=8.8 \mathrm{~Hz}, \mathrm{H}-2,6) ;{ }^{13} \mathrm{C}$ NMR (methanol- $\left.d_{4}\right)$ $\delta_{\mathrm{C}} 66.2(\mathrm{C}-9), 69.0\left(\mathrm{C}-8^{\prime}\right), 82.6\left(\mathrm{C}-7^{\prime}\right), 116.1(\mathrm{C}-3,5), 116.1$ $\left(\mathrm{C}-3^{\prime}, 5^{\prime}\right), 124.5(\mathrm{C}-8), 128.7(\mathrm{C}-2,6), 130.2\left(\mathrm{C}-2^{\prime}, 6^{\prime}\right)$, $131.5(\mathrm{C}-1), 132.1\left(\mathrm{C}-1^{\prime}\right), 139.8$ (C-7), 158.0 (C-4), 158.5 $\left(\mathrm{C}-4^{\prime}\right)$.

14. The ${ }^{1} \mathrm{H}$ and ${ }^{13} \mathrm{C}$ NMR spectra of 4 were assigned with the aid of NOESY, ${ }^{1} \mathrm{H}-{ }^{1} \mathrm{H}$ COSY, DEPT, HSQC and HMBC experiments.

15. Finlay, G. J.; Baguley, B. C.; Wilson, W. R. Anal. Biochem. 1984, 139, 272-277. 